International Journal of

Supply Chain and Logistics

(IJSCL)

INFLUENCE OF SUPPLY CHAIN SUSTAIXY PERFORMANCE OF COMPANIES IN THE OIY?

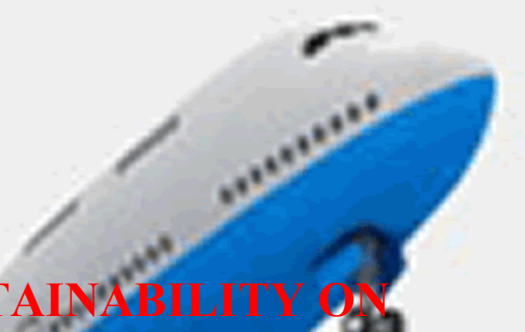

INRENYA.

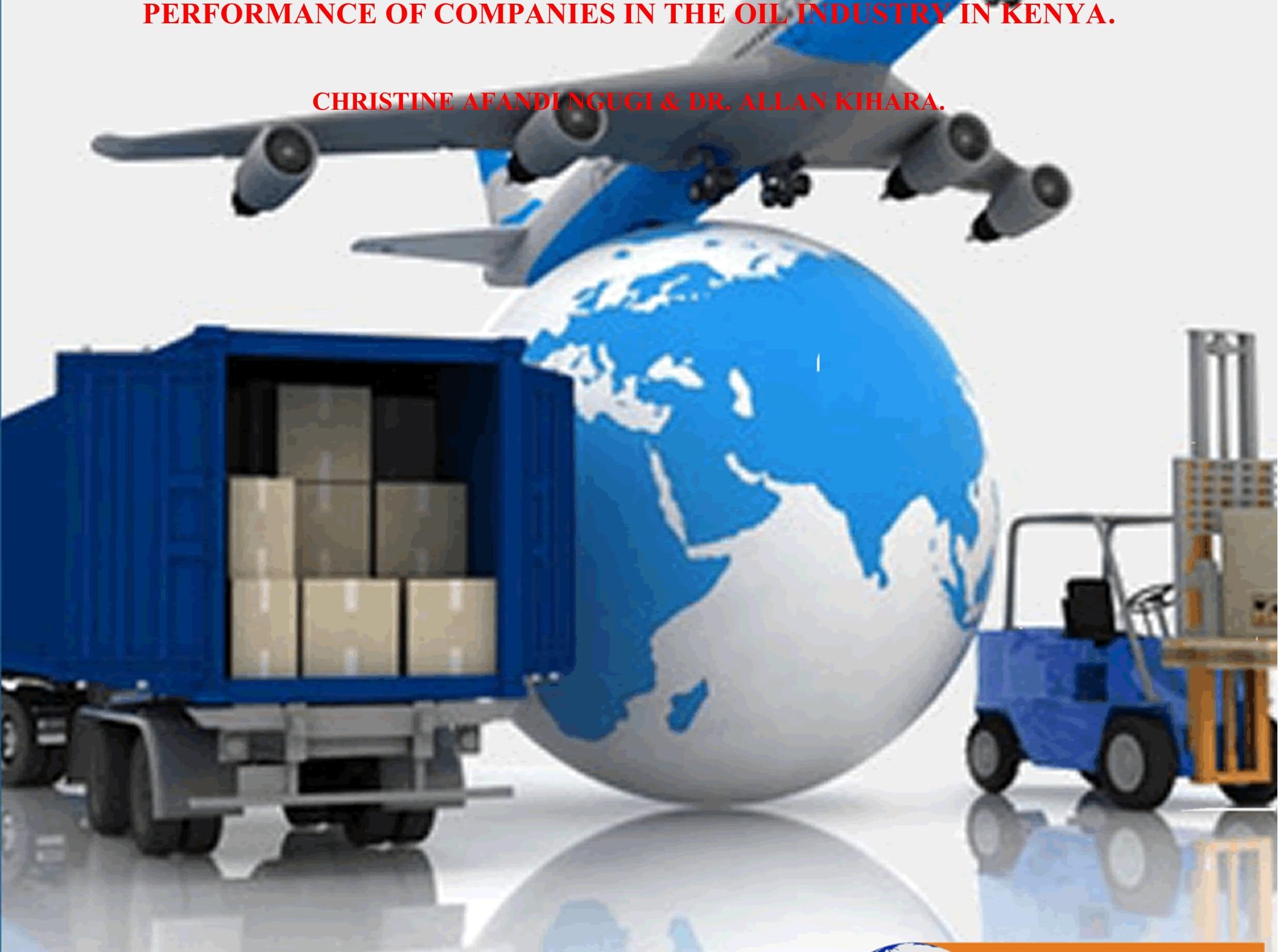


International Journal of Supply Chain and

Logistics ISSN 2520-3983 (Online)

Vol. 3, Issue 2, pp 84 - 104, 2019

\title{
INFLUENCE OF SUPPLY CHAIN SUSTAINABILITY ON PERFORMANCE OF COMPANIES IN THE OIL INDUSTRY IN KENYA.
}

\author{
${ }^{1 *}$ Christine Afandi Ngugi \\ ${ }^{1}$ Post graduate student, Jomo Kenyatta University of Agriculture and Technology \\ ${ }^{2}$ Dr. Allan Kihara Ph.D. \\ Lecturer, Jomo Kenyatta University of Agriculture and Technology \\ P. O. Box 62000, 00200 Nairobi, Kenya. \\ *Corresponding Author email: afandi.ngugi@gmail.com
}

\begin{abstract}
Purpose: The purpose of the study was to examine the influence of supply chain sustainability on performance of companies in the oil industry in Kenya with an aim of making recommendations on proper use of supply chain sustainability strategies. The study aimed at establishing how reverse logistics management, information technology adoption, early vendor involvement and green procurement adoption influences performance of companies in the oil industry. To achieve this, the study reviewed both theoretical and empirical literature and proposed the research methodology that addressed the gaps identified in literature as well as answer the stipulated research questions.
\end{abstract}

Methodology: This research study adopted a descriptive research design approach targeting procurement staff at the 53 oil companies. This method is preferred because it allows an in-depth study of the subject. To gather data, structured questionnaire was used to collect data from 159 procurement officers, who were selected using simple random sampling, from the three strata. Once collected, data was analysed using descriptive and inferential statistics. Quantitative data was analysed using multiple regression analysis. The qualitative data generated was analysed by use of Statistical Package of Social Sciences (SPSS) version 22.

Results: The response rate of the study was $75 \%$. The findings of the study indicated that reverse logistics management, information technology adoption, early vendor involvement and green procurement adoption have a positive relationship with performance in companies in the oil industry.

Contributions to policy and practice: The study recommended that companies in the oil industry should embrace supply chain sustainability so as to improve performance and further researches should to be carried out in other institutions to find out if the same results can be obtained.

Key Words: Reverse Logistics Management, Information Technology Adoption, Early Vendor Involvement, Green Procurement Adoption And Performance Of Companies 
International Journal of Supply Chain and

Logistics ISSN 2520-3983 (Online)

Vol. 3, Issue 2, pp 84 - 104, 2019

\subsection{INTRODUCTION}

Driven by legislation and increasing environmental awareness, sustainability has become an important issue among leading organizations, research institutions and policy-makers at national and international levels (Christmann, 2010). Within organizations sustainability issues lie with strategic level decision-making on corporate social responsibility and carry serious implications for purchasing and supply chain management. The origin of sustainability may date back to over 135 years ago from an idea known as spaceship earth evolving over the years, the construct gained significant popularity with the emergence of the term 'Sustainable Development' from the Brundtland Report. The report defined the term as the development that meets the needs of the present generation without compromising the ability of the future generations to meet their own needs (Christopher, 2010). The three main pillars of sustainable development include economic growth, environmental protection, and social equality. While many people agree that each of these three ideas contribute to the overall idea of sustainability, it is difficult to find evidence of equal levels of initiatives for the three pillars in countries' policies worldwide (Duber, 2012). With the overwhelming number of countries that put economic growth on the forefront of sustainable development, it is evident that the other two pillars have been suffering, especially with the overall well-being of the environment in a dangerously unhealthy state. In more general terms, sustainability is the endurance of systems and processes. The organizing principle for sustainability is sustainable development, which includes the four interconnected domains: ecology, economics, politics and culture (Hall \& Matos, 2010). Sustainability can also be defined as a socio-ecological process characterized by the pursuit of a common ideal. An ideal is by definition unattainable in a given time and space. However, by persistently and dynamically approaching it, the process results in a sustainable system (Lehtonen, 2014). A supply chain is a system of organizations, people, activities, information, and resources involved in moving a product or service from supplier to customer. Supply chain activities involve the transformation of natural resources, raw materials, and components into a finished product that is delivered to the end customer. In sophisticated supply chain systems, used products may re-enter the supply chain at any point where residual value is recyclable. Supply chains link value chains (Hoffman, 2011).

\subsection{Statement of the problem}

Sustainability has become a prominent term in different contexts. There is a growing need for integrating environmentally sound choices into supply-chain management. According to a World Bank Report (2014) sustainable supply chains consistently use social impact assessments. In Kenya companies in the oil industry accounted for $6 \%$ of the country's Gross Domestic Product (GDP), provided employment opportunities to about 600,000 people. However, companies in the oil industry in Kenya have been experiencing a myriad of problems including non-sustainability of their supply chains (USAID, 2014). According to a report by Delloite (2014) in Kenya, out of a sample of 30 companies in the oil industry, only 11 had adopted sustainability practices. Among many other reasons cited, this resulted to losses amounting to over 13 Million at Shell BP in the (FY) 2013/2014. In a customer satisfaction survey of 2012 and 2013, carried out by $\mathrm{m} / \mathrm{s}$ House of Procurement Consultants, it was visibly notable that the percentage index had been decreasing that is, 52\% and 43\% respectively (Shale \& Rahma, 2014). Shell BP faces a major challenge in controlling the overall operating cost because of the constant increase of sourcing 
cost due to lack of sustainability strategies; this is evident by Shell BP posting a decrease in profit prior to tax of Sh1.2 billion compared to Sh1.8 billion noted in the previous year according to a Shell BP 2011 annual report. A research carried out on the state of environmental impact among companies in the oil industry in Kenya by CCG (2014) revealed that the negative environmental impact of companies in the oil industry is quite high while at the same time they continue to import more oil and consumer numbers continue increasing, becoming a principal cause of long term environmental problems (GoK, 2014). This raises questions on the level of sustainability strategies of companies in the oil industry procurement procedures. Several studies have been done, at the global level; Chien and Shih (2011) point out lack of sustainability due to low level of awareness, approaches used by companies and lack of proper feasibility study. They surveyed Japanese companies in the oil industry and reported a link between sustainability strategy and performance. They noted that sustainability strategy ensures strategic alliances are forged and aspects such as green procurement adopted. Locally, Shale and Rahma (2014) found that Eco-design practices had a direct impact on the performance of manufacturing firms. Swalehe and Odock (2015) concluded that sustainability planning and strategies have a direct positive impact on the performance of manufacturing firms. While much research has focused on the problems facing the general performance of companies, not much research has been done to study sustainability and there influence on performance of companies in the oil industry in Kenya. It is against this back drop that this study aims at assessing the influence of supply chain sustainability on performance of companies in the oil industry in Kenya.

\subsection{Research objectives}

i. To establish the influence of reverse logistics management on performance of companies in the oil industry in Kenya.

ii. To determine the influence of information technology adoption on performance of companies in the oil industry in Kenya.

iii. To assess the influence of early vendor involvement on performance of companies in the oil industry in Kenya.

iv. To determine the influence of green procurement adoption on performance of companies in the oil industry in Kenya.

\subsection{LITERATURE REVIEW}

\subsection{Theoretical Review}

\subsubsection{The Stakeholder Theory}

According to Harrison and Freeman (2015), they defined the concept of a stakeholder approach in relation to reverse logistics management to include any individual or group who can affect the firm's performance or who is affected by the achievement of the organizations' objectives. The stakeholder theory is grouped into two: strategic stakeholder who emphasizes the active management of stakeholder interests and moral stakeholder interested in balancing stakeholder interests (Frooman, 2015). Corporations should not focus narrowly their strategic management decisions on creating shareholder value; rather broaden their objectives to tackle the expectations and interest of a wide variety of salient stakeholders (Donaldson \& Preston, 2015). Poor reverse logistics management leads to poor company's relationship with its stakeholders. Consequently shareholders and financial institutions perceive companies with a poor environmental record as 
riskier to invest in and may demand a higher risk premium (Henriques \& Sadorsky, 2015). Also companies with a poor reputation of reverse logistics management will find it harder to attract and retain highly qualified employees who may have a strong proactive environmental management (Reinhardt, 2015). From the above argument the success of companies aiming to develop reverse logistics competencies strongly depend on the participation of their employees. Consumer awareness has led them to demand industry improvement on their environmental performance (Buysse \& Verbeke, 2013). Consumers can reject the products of companies with poor reverse logistics management reputation (Greeno \& Robinson, 2012). Similarly suppliers may stop delivering inputs to protect their own reputation. A firm with a reactive reverse logistics management may face big loss of competitive advantage if proactive environmental management becomes a common practice among its competitors. From the above argument Freeman and Phillips, (2012) suggest that business should take a leadership role to improve the natural environment. In this study stakeholder theory has been adopted and linked to reverse logistics management variable.

\subsubsection{Innovation Diffusion Theory}

Diffusion of innovations is a theory that seeks to explain how, why, and at what rate new ideas and technology spread. Everett Rogers, popularized the theory in his book Diffusion of Innovations; the innovation must be widely adopted in order to self-sustain. Diffusion of Innovation (DOI) theory is a popular model used in information systems research to explain user adoption of new technologies (Davila, 2010). An innovation is an idea or object that is perceived to be new. According to DOI, the rate of diffusion is affected by an innovation's relative advantage, complexity and compatibility. Croom and Jones (2010) define relative advantage as 'the degree to which an innovation is seen as being superior to its predecessor'. Complexity, which is comparable to perceived ease of use construct, is 'the degree to which an innovation is seen by the potential adopter as being relatively difficult to use and understand'. Compatibility refers to 'the degree to which an innovation is seen to be compatible with existing values, beliefs, experiences and needs of adopters' (Samuelson, 2013). The advantage of the improved system is that it has allowed for better communication between the vendors and companies in the oil industry since they have to communicate to ensure that less time is taken to replenish inventory (Jha, 2010). Companies in the oil industry, aided by technological developments, have responded to the challenges they face by adopting a new strategy, which emphasizes on attempting to build customer satisfaction through offering better products and services and at the same time to minimize operation costs. The diffusion theory is relevant because it explains the reason why companies in the oil industry adopt technical innovations. One of the reasons why companies in the oil industry adopt technical innovations is relevant advantage. This means that companies in the oil industry that adopt technical innovations have relatively better financial advantage than those who do not (Kitheka, 2012).

\subsubsection{The Legitimacy Theory}

According to Islam (2014) legitimacy is a generalized perception or assumption that the actions of an entity are desirable, proper or appropriate within some socially constructed system of norms, values and beliefs. According to Shirima (2013) the theory suggests that organizations always try to ensure that they operate within the defined norms and boundaries of their respective societies. In simpler terms, the notion behind legitimacy theory is that there is a social 
bond existing between the organization and the society within which it operates (Guthrie et al., 2014). Islam (2014) put-forward that legitimacy management is heavily dependent on communication, and thus, to understand legitimacy theory some forms of early supplier involvement must be examined. Baumann-Pauly (2013) however believes that legitimacy is not necessarily only a gentle process for organizations to gain legitimacy from the society. She suggested two broad legitimation strategies that an organization can employ on encountering different legitimation threats. First, an organization can seek to educate stakeholders about its intentions to improve their welfare. Second, the organization might attempt to change the perceptions of the relevant public, by involving the local suppliers early in their development stage without changing the organization's actual performance. Baumann-Pauly (2013) then concluded that legitimacy can be considered as the key reason to involve suppliers early in the process and their consequent development. This theory is in this study has been linked to early vendor involvement because the legitimacy that an organization gains in a society is determined by the early iniatives it takes concerning its vendors.

\subsubsection{Resource Dependency Theory}

RDT presents a premier framework for understanding the relationship between the organization and the environment (Brettel \& Voss, 2013). Anne and Hellen (2015) hold that, sustainable SCM and stakeholder pressure influence the strategies that organizations employ to improve their economic sustainability. RDT suggests that as both the buyer and the supplier become more dependent on one another, both parties will seek stability in the relationship to minimize their risks. As a result, the companies' integration becomes a normative aspect of the relationship (Beske \& Seuring, 2014). As related to our topic, sustainable supply chain management (SSCM)related practices that the First-Tier (FT) supplier adopts depends on how well downstream customers' expectations are aligned with the materials that sub-suppliers provide and the sustainability of upstream production processes (Amol \& Ashish, 2016). Once focus and depth are aligned, both parties become more willing to invest in resources that reduce uncertainty and prevent supply chain disruptions, be they caused by natural events or through sustainability misconduct at the sub-supplier level (Drees \& Heugens, 2013).

One of the fundamental assumptions of RDT is that organizations are not self-sufficient, but rely on their environment and its resources for survival and achievement of long-term objectives (Fouka \& Mantzorou, 2011). Organizations obtain critical resources by looking outside their boundaries. The RDT perspective is particularly pertinent when sustainability-related risks of the buying Original Equipment Manufacturer (OEM) are a matter of concern. Sustainability-related risk becomes an issue when the supply base's potential negative deviation from expected sustainability behavior may lead to reputational damage for the buying OEM (Grandia, Steijn \& Kuipers, 2015). Such risks are particularly troubling because the OEM does not have direct and full control over the FT suppliers' and sub-suppliers' behaviors, but the OEM's public legitimacy and reputation depend on these parties' business conduct (Spence \& Bourlakis, 2015). RDT is a central theory in scholarly and applied understandings of the relationship between sustainable SCM, stakeholder pressure, and corporate sustainability performance. RDT lends support to the concept that organizations should proactively engage in sustainable SCM because sustainable SCM resolves a resource dependency problem, reduces stakeholder pressure, and ensures sustainable profitability (Sarkis, 2012). This theory is in this study has been linked to green 
International Journal of Supply Chain and

Logistics ISSN 2520-3983 (Online)

Vol. 3, Issue 2, pp 84 - 104, 2019

procurement adoption because the resources that an organizations deploys in a society determines success of economical sustainability.

\subsection{Conceptual framework}

\section{Reverse Logistics Management}

- Returns Policy and Remanufacturing

- Recall Programs and Procedures

\section{Information Technology Adoption}

- Electronic Points of Sale

- Electronic Data Interchange

\section{Early Vendor Involvement}

- Alignment of Goals and Vision

- Joint Planning and Activities

\section{Green Procurement Adoption}

- Eco-Material Sourcing \& Selection

- Eco-Products Designs

\section{Independent variables}

Performance of Companies in the Oil Industry

- Cost Reduction

- Profits

- Timalr nalivarias

\section{Figure 1: Conceptual Framework}

\subsection{RESEARCH METHODOLOGY}

The study adopted a descriptive research design and targeted 53 licensed oil companies in Kenya that are in three tiers as listed by Petroleum Institute of East Africa (2017). Stratified random sampling was used to determine the study sample of 159 . The unit of analysis comprised of procurement staffs in the three tier petrol stations. Primary data was collected through questionnaires while secondary data was gathered from existing credible and recognized sources. Inferential and descriptive statistics was used to analyse data. Results of the analysis were presented by use of tables and figures. Inferential statistics was used to establish the association between independent variables and dependent variable. The study used the following regression model:

$Y=\beta_{0}+\beta_{1} X_{1}+\beta_{2} X_{2}+\beta_{3} X_{3}+\beta_{4} X_{4}+\varepsilon$ 
International Journal of Supply Chain and

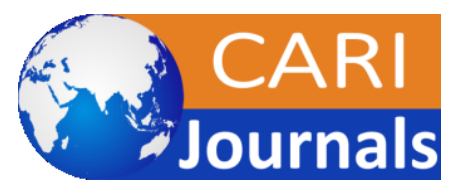

Logistics ISSN 2520-3983 (Online)

Vol. 3, Issue 2, pp 84 - 104, 2019

Where $\mathbf{Y}=$ Performance of companies in the oil industry, $\boldsymbol{\beta 0}=$ Constant, $\beta 1, \beta 2, \beta 3, \beta 4=$ Beta Coefficients, $\mathbf{X}_{\mathbf{1}}=$ Reverse Logistics Management, $\mathbf{X}_{\mathbf{2}}=$ Information Technology Adoption, $\mathbf{X}_{\mathbf{3}}=$ Early Vendor Involvement, $\mathbf{X}_{\mathbf{4}}=$ Green Procurement Adoption and $\boldsymbol{\varepsilon}=$ Error Term.

\subsection{RESULTS}

\subsection{Response rate}

The study administered 159 questionnaires where 119 questionnaires were filled and returned. This represented a response rate of $75 \%$. This was above the $50 \%$ which is considered adequate in descriptive statistics according to Mugenda and Mugenda (2013).

\subsection{Descriptive statistics}

\section{Reverse Logistics Management}

The respondents were asked to indicate to what extent reverse logistics management influenced performance of companies in the oil industry in Kenya. Results indicated that majority of the respondents $33 \%$ agreed that it was to a very great extent, $19 \%$ said that it was to a great extent, $30 \%$ said it was moderate, while little extent was $11 \%$ and not all was at $7 \%$ respectively.

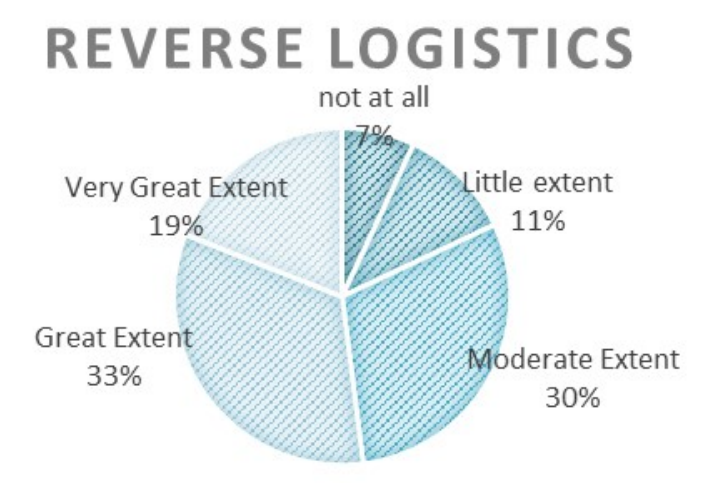

\section{Figure 2: Reverse Logistics}

The respondents were also asked to comment on statements regarding reverse logistics management influence on performance of companies in the oil industry. The responses were rated on a likert scale and the results presented in table 1 below. and was rated on a 5 point Likert scale ranging from; $1=$ strongly disagree to $5=$ strongly agree. The scores of ' strongly disagree' and 'disagree' have been taken to represent a statement not agreed upon, equivalent to mean score of 0 to 2.5. The score of 'neutral' has been taken to represent a statement agreed upon, equivalent to a mean score of 2.6 to 3.4. The score of 'agree' and 'strongly agree' have been taken to represent a statement highly agreed upon equivalent to a mean score of 3.5 to 5 . Results indicated that majority of the respondents as indicated by a mean of 4.2 agreed on the statement that returns policy and remanufacturing plays a significant influence in cost reduction. The variations in the responses were shown by a standard deviation of 1.0. Results indicated that majority of the respondents as indicated by a mean of 3.6 agreed on the statement that recall programs and procedures plays a significant influence in cost reduction The variations in the responses was shown by a standard deviation of 1.3 Results indicated that majority of the respondents as indicated by a mean of 3.6 agreed on the statement that recycling and refurbishment plays a significant influence in cost reduction The variations in the responses was 
shown by a standard deviation of 1.3. Results indicated that majority of the respondents as indicated by a mean of 3.3 agreed on the statement that returns policy and remanufacturing plays a significant influence in attaining higher profits. The variations in the responses were shown by a standard deviation of 1.3. Results indicated that majority of the respondents as indicated by a mean of 4.2 agreed on the statement that recalls programs and procedures play a significant influence in attaining higher profits. The variations in the responses were shown by a standard deviation of 0.9 . Results indicated that majority of the respondents as indicated by a mean of 3.8 agreed on the statement that recycling and refurbishment plays a significant influence in attaining higher profits.The variations in the responses was shown by a standard deviation of 0.6. Results indicated that majority of the respondents as indicated by a mean of 4.1 agreed on the statement that returns policy and remanufacturing plays a significant influence in reducing delivery time. The variations in the responses were shown by a standard deviation of 0.6 . Results indicated that majority of the respondents as indicated by a mean of 3.9 agreed on the statement that recycling and refurbishment plays a significant influence in reducing delivery time .The variations in the responses was shown by a standard deviation of 0.6 . The average result for statements on reverse logistics management was 3.8 while the standard deviation was 1.4 . The findings agree with Odundo (2012) that practicing reverse logistics management when sourcing can be smart but if not done well can prove to be expensive and time consuming.

Table 1: Reverse Logistics

\begin{tabular}{llll}
\hline Statements & N & Mean & $\begin{array}{l}\text { Std. } \\
\text { Dev }\end{array}$ \\
\hline $\begin{array}{l}\text { Returns policy and remanufacturing plays a significant influence in cost reduction } \\
\text { Recall programs and procedures plays a significant influence in cost reduction }\end{array}$ & 119 & 4.2 & 1.0 \\
$\begin{array}{l}\text { Recycling and refurbishment plays a significant influence in cost reduction } \\
\text { Returns policy and remanufacturing plays a significant influence in attaining }\end{array}$ & 119 & 3.6 & 1.3 \\
$\begin{array}{l}\text { higher profits } \\
\text { Recall programs and procedures plays a significant influence in attaining higher } \\
\text { profits }\end{array}$ & 119 & 3.3 & 1.4 \\
$\begin{array}{l}\text { Recycling and refurbishment plays a significant influence in attaining higher } \\
\text { profits }\end{array}$ & 119 & 4.2 & 0.9 \\
$\begin{array}{l}\text { Returns policy and remanufacturing plays a significant influence in reducing } \\
\text { delivery time }\end{array}$ & 119 & 3.8 & 0.6 \\
$\begin{array}{l}\text { Recall programs and procedures plays a significant influence in reducing delivery } \\
\text { time }\end{array}$ & 119 & 4.1 & 3.3 \\
$\begin{array}{l}\text { Recycling and refurbishment plays a significant influence in reducing delivery } \\
\text { time }\end{array}$ & 119 & 3.9 & 1.1 \\
Average & $\mathbf{1 1 9}$ & $\mathbf{3 . 8}$ & $\mathbf{1 . 4}$ \\
\hline
\end{tabular}

\section{Information Technology Adoption}

The respondents were asked to indicate to what extent did information technology adoption influenced performance of companies in the oil industry in Kenya. Results indicated that majority of the respondents $37 \%$ agreed that it was to a very great extent, $33 \%$ said that it was to a great extent, 19\% said it was moderate, while little extent and not all tied were at 4 and $7 \%$ respectively. 
International Journal of Supply Chain and

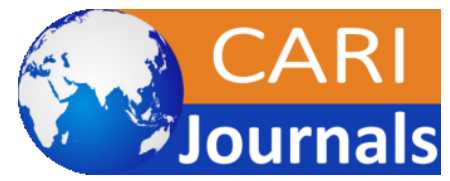

Logistics ISSN 2520-3983 (Online)

Vol. 3, Issue 2, pp 84 - 104, 2019

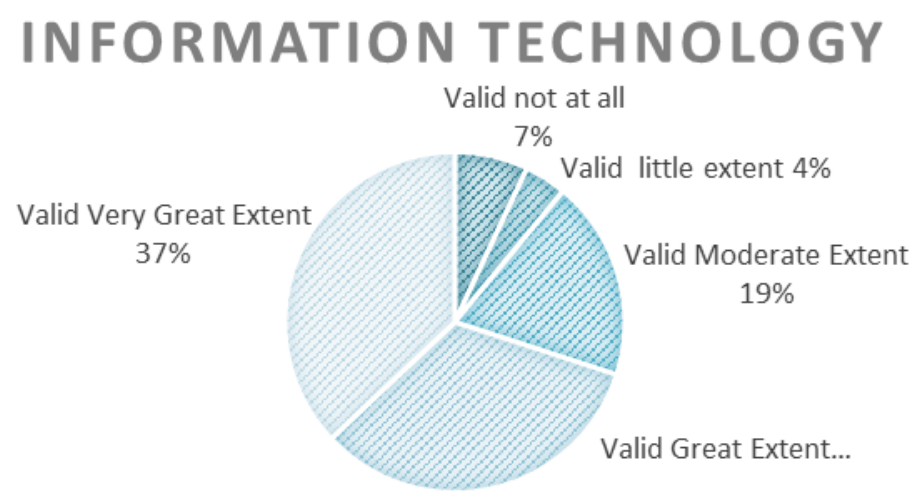

\section{Figure 3: Information Technology Adoption}

The respondents were also asked to comment on statements regarding the influence of information technology adoption on performance of companies in the oil industry in Kenya. Results indicated that majority of the respondents indicated by a mean of 3.8 agreed on statements that electronic points of sale plays a significant influence in cost reduction. The variation was 1.2. Results indicated that majority of the respondents indicated by a mean of 3.5 agreed on the statement that electronic data interchange plays a significant influence in cost reduction. The variation was 1.1 . Results indicated that majority of the respondents indicated by a mean of 3.7 agreed on the statement that vendor managed inventory system plays a significant influence in cost reduction. The variation was 1 . Results indicated that majority of the respondents indicated by a mean of 3.5 agreed on the statement that electronic points of sale plays a significant influence in attaining higher profits. The variation was 1 . Results indicated that majority of the respondents indicated by a mean of 3.6 agreed on the statement that electronic data interchange plays a significant influence in attaining higher profits. The variation was 1.2. Results indicated that majority of the respondents indicated by a mean of 3.5 agreed on the statement that vendor managed inventory system plays a significant influence in attaining higher profits. The variation was 1.3 . Results indicated that majority of the respondents indicated by a mean of 3.5 agreed on the statement that electronic points of sale plays a significant influence in reducing delivery time. The variation was 1.3. Results indicated that majority of the respondents indicated by a mean of 3.4 agreed on the statement that electronic data interchange plays a significant influence in reducing delivery time. The variation was 1.4 . Results indicated that majority of the respondents indicated by a mean of 3.4 agreed on the statement that vendor managed inventory system plays a significant influence in reducing delivery time. The variation was 0.5 . The average of the statements on information technology adoption was 3.6 while the variations in the responses were given at 1.1. These findings agree with Nyariki (2013) that organizations must look toward information technology system for improvements. The opportunities for cost savings can be enormous as the impact on margins and bottom line is considerable. 
International Journal of Supply Chain and

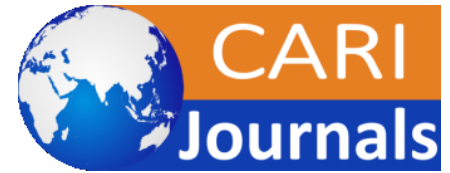

Logistics ISSN 2520-3983 (Online)

Vol. 3, Issue 2, pp 84 - 104, 2019

Table 2: Information Technology Adoption

\begin{tabular}{|c|c|c|c|}
\hline Statements & $\mathbf{N}$ & Mean & Std. Dev \\
\hline Electronic points of sale plays a significant influence in cost reduction & 119 & 3.8 & 1.2 \\
\hline Electronic data interchange plays a significant influence in cost reduction & 119 & 3.5 & 1.1 \\
\hline $\begin{array}{l}\text { Vendor managed inventory system plays a significant influence in cost } \\
\text { reduction }\end{array}$ & 119 & 3.7 & 1.0 \\
\hline $\begin{array}{l}\text { Electronic points of sale plays a significant influence in attaining higher } \\
\text { profits }\end{array}$ & 119 & 3.5 & 1.1 \\
\hline $\begin{array}{l}\text { Electronic data interchange plays a significant influence in attaining } \\
\text { higher profits }\end{array}$ & 119 & 3.6 & 1.2 \\
\hline $\begin{array}{l}\text { Vendor managed inventory system plays a significant influence in } \\
\text { attaining higher profits }\end{array}$ & 119 & 3.5 & 1.3 \\
\hline $\begin{array}{l}\text { Electronic points of sale plays a significant influence in reducing delivery } \\
\text { time }\end{array}$ & 119 & 3.5 & 1.3 \\
\hline $\begin{array}{l}\text { Electronic data interchange plays a significant influence in reducing } \\
\text { delivery time }\end{array}$ & 119 & 3.4 & 1.4 \\
\hline $\begin{array}{l}\text { Vendor managed inventory system plays a significant influence in } \\
\text { reducing delivery time }\end{array}$ & 119 & 3.6 & 0.5 \\
\hline Average & 119 & 3.6 & 1.1 \\
\hline
\end{tabular}

Early Vendor Involvement

There was also need to establish how early vendor involvement influenced performance of oil companies in Kenya as the third objective. The respondents were asked to comment on extent of early vendor involvement influence performance of oil companies in Kenya. Results indicated that majority of the respondents $48 \%$ agreed that it was to a very great extent, $45 \%$ said that it was to a great extent, $2 \%$ said it was moderate, little extent was $2 \%$ and not all at $3 \%$.

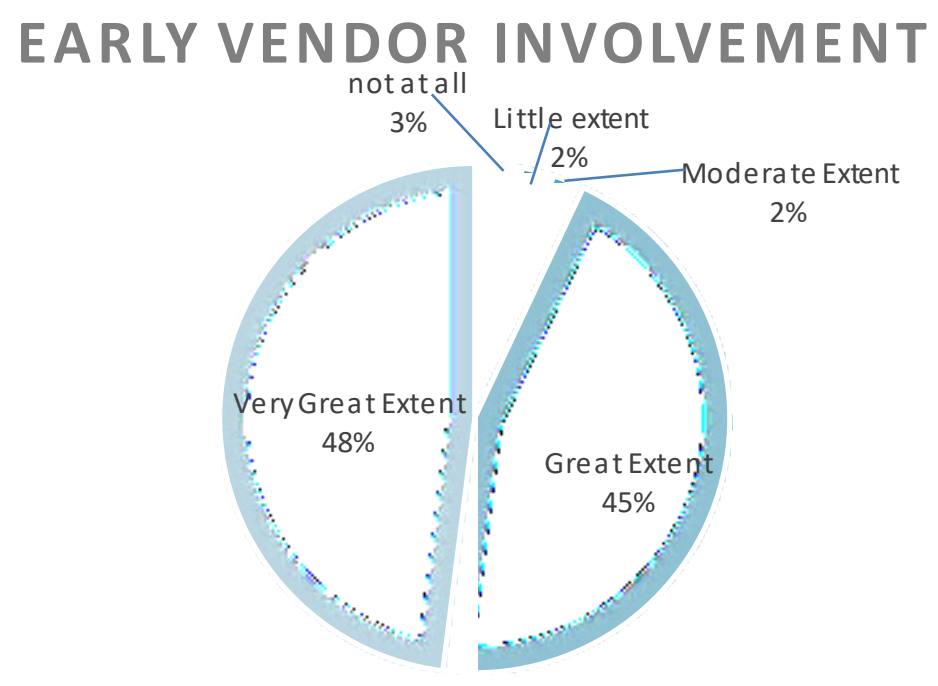


International Journal of Supply Chain and

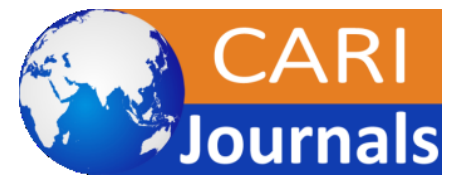

Logistics ISSN 2520-3983 (Online)

Vol. 3, Issue 2, pp 84 - 104, 2019

Figure 4: Early Vendor Involvement

Table 3: Early Vendor Involvement

\begin{tabular}{llll}
\hline Statements & N & Mean & $\begin{array}{c}\text { Std. } \\
\text { Dev }\end{array}$ \\
\hline Alignment of goals and vision plays a significant influence in cost reduction & 119 & 4.0 & 1.1 \\
Joint planning and activities plays a significant influence in cost reduction & 119 & 3.4 & 1.3 \\
Systems integration plays a significant influence in cost reduction & 119 & 4.1 & 0.8 \\
$\begin{array}{l}\text { Alignment of goals and vision plays a significant influence in attaining higher } \\
\text { profits }\end{array}$ & & & \\
Joint planning and activities plays a significant influence in attaining higher & & & \\
profits & 119 & 3.7 & 0.7 \\
Systems integration plays a significant influence in attaining higher profits & 119 & 2.8 & 1.3 \\
Alignment of goals and vision plays a significant influence in reducing delivery & & & \\
time & 119 & 3.2 & 1.2 \\
Joint planning and activities plays a significant influence in reducing delivery time & 119 & 3.4 & 1.2 \\
Systems integration plays a significant influence in reducing delivery time & 119 & 3.6 & 1.3 \\
Average & $\mathbf{1 1 9}$ & $\mathbf{3 . 6}$ & $\mathbf{1 . 1}$ \\
\hline
\end{tabular}

The respondents were also asked to comment on statements regarding: early vendor involvement influence performance in oil sector in Kenya. Results indicated that majority of the respondents as shown by a mean of 4.0 agreed on the statement that alignment of goals and vision plays a significant influence in cost reduction. The standard deviation for the results responses was 1.1. Results indicated that majority of the respondents as shown by a mean of 4.4 agreed on the statement that joint planning and activities plays a significant influence in cost reduction. The standard deviation for the results responses was 1.3. Results indicated that majority of the respondents as shown by a mean of 3.4 agreed on the statement that systems integration plays a significant influence in cost reduction. The standard deviation for the results responses was .8. Results indicated that majority of the respondents as shown by a mean of 3.4 agreed on the statement that alignment of goals and vision plays a significant influence in attaining higher profits. The standard deviation for the results responses was 1.3. Results indicated that majority of the respondents as shown by a mean of 3.7 agreed on the statement that joint planning and activities plays a significant influence in attaining higher profits. The standard deviation for the results responses was .7. Results indicated that majority of the respondents as shown by a mean of 2.8 agreed on the statement that systems integration plays a significant influence in attaining higher profits. The standard deviation for the results responses was .7. Results indicated that majority of the respondents as shown by a mean of 3.2 agreed on the statement that alignment of goals and vision plays a significant influence in reducing delivery time. The standard deviation for the results responses was 1.2. Results indicated that majority of the respondents as shown by a mean of 3.4 agreed on the statement that joint planning and activities plays a significant influence in reducing delivery time. The standard deviation for the results responses was 1.2. Results indicated that majority of the respondents as shown by a mean of 3.6 agreed on the statement that systems integration plays a significant influence in reducing delivery time. The standard deviation for the results responses was 1.3. The average for all the responses was 3.6 and a standard deviation of 1.2. These findings imply that through early vendor involvement, 
International Journal of Supply Chain and

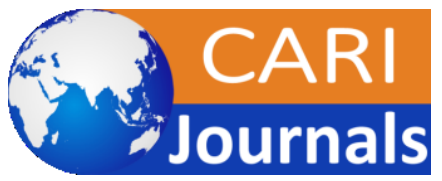

Logistics ISSN 2520-3983 (Online)

Vol. 3, Issue 2, pp 84 - 104, 2019

companies can improve competitive positioning, gain entry to new dynamic, technology driven markets, supplement critical skills and share the risk (Noor, Guyo \& Amuhaya, 2013).

\section{Green Procurement Adoption}

There was also need to establish how green procurement adoption influences performance among oil companies in Kenya. Results also showed that majority of the respondents indicated great extent performance of the company was $10 \%$, very great extent was $3 \%$, not at all was $30 \%$ while little extent and moderate extent was $22 \%$ and $35 \%$ respectively.

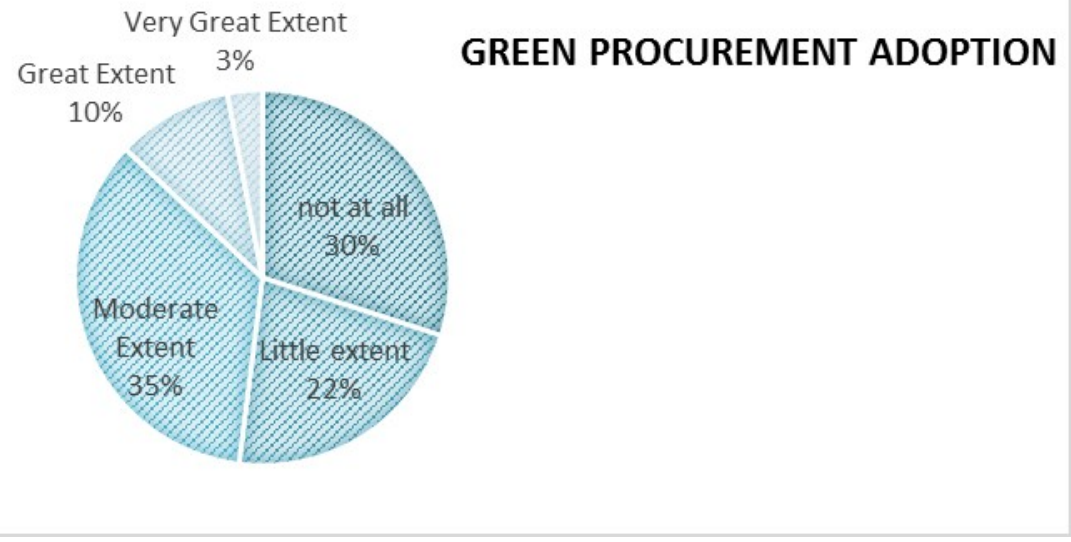

\section{Figure 5: Green Procurement Adoption}

Results indicated that majority of the respondents agreed on the statement that eco-material sourcing and selection plays a significant influence in cost reduction. The mean for this statement was 2.8 while the standard deviation the variation in the responses was 1.4. Results indicated that majority of the respondents agreed on the statement that eco-products designs plays a significant influence in cost reduction. The mean for this statement was 3.3 while the standard deviation the variation in the responses was 1.4. Results indicated that majority of the respondents agreed on the statement that eco-products designs play a significant influence in cost reduction. The mean for this statement was 3.3 while the standard deviation the variation in the responses was 1.1. Results indicated that majority of the respondents agreed on the statement that Eco-manufacturing processes plays a significant influence in cost reduction. The mean for this statement was 4.2 while the standard deviation the variation in the responses was .9. Results indicated that majority of the respondents agreed on the statement that eco-material sourcing and selection plays a significant influence in attaining higher profit. The mean for this statement was 4.1 while the standard deviation the variation in the responses was 1.2. Results indicated that majority of the respondents agreed on the statement that eco-manufacturing processes plays a significant influence in attaining higher profits. The mean for this statement was 4.3 while the standard deviation the variation in the responses was .7. Results indicated that majority of the respondents agreed on the statement that eco-material sourcing and selection plays a significant influence in reducing delivery time. The mean for this statement was 4.4 while the standard deviation of the variation in the responses was .8. Results indicated that majority of the respondents agreed on the statement that eco-products designs plays a significant influence in reducing delivery time. The mean for this statement was 4.4 while the standard deviation the 
variation in the responses was .6. Results indicated that majority of the respondents agreed on the statement that eco-manufacturing processes plays a significant influence in reducing delivery time. The mean for this statement was 4 while the standard deviation the variation in the responses was .6. The average for the statements on green procurement was 4.0 with a standard deviation of .9 .

The results imply that an organization benefits greatly when green procurement is embraced to reduce costs, introduce eco-material designed to address the organization's needs, and work with the organization to streamline sourcing management (Mwenda, 2012).

Table 4: Green Procurement Adoption

\begin{tabular}{llll}
\hline Statements & N & Mean & Std. Dev \\
\hline Eco-material sourcing and selection plays a significant influence in cost reduction & 119 & 2.8 & 1.4 \\
Eco-products designs plays a significant influence in cost reduction & 119 & 3.3 & 1.1 \\
Eco-manufacturing processes plays a significant influence in cost reduction & 119 & 4.2 & 0.9 \\
Eco-material sourcing and selection plays a significant influence in attaining higher profits & 119 & 4.1 & 1.2 \\
Eco-products designs plays a significant influence in attaining higher profits & 119 & 4.2 & 0.9 \\
Eco-manufacturing processes plays a significant influence in attaining higher profits & 119 & 4.3 & 0.7 \\
Eco-material sourcing and selection plays a significant influence in reducing delivery time & 119 & 4.4 & 0.6 \\
Eco-products designs plays a significant influence in reducing delivery time & 119 & 4.4 & 0.8 \\
Eco-manufacturing processes plays a significant influence in reducing delivery time & 119 & 4.4 & 0.6 \\
Average & $\mathbf{1 1 9}$ & $\mathbf{4 . 0}$ & $\mathbf{0 . 9}$ \\
\hline
\end{tabular}

\section{Inferential Analysis}

Inferential analysis was used to determine both the significance and degree of association of the variables and also predict the level of variation in the dependent variable caused by the independent variables. The correlation technique is used to analyze the degree of association between two variables. The results of the correlation analysis are summarized in Table 5. The correlation summary shown in Table 5 indicates that the associations between each of the independent variables and the dependent variable were all significant at the $95 \%$ confidence level. The correlation analysis to determine the influence of supply chain sustainability on the performance of companies in the oil industry in Kenya, Pearson Correlation Coefficient computed and tested at 5\% significance level. The results indicate that there is a positive relationship $(\mathrm{r}=0.479)$ between reverse logistics management and performance of oil companies in Kenya. In addition, the researcher found the relationship to be statistically significant at $5 \%$ level $(\mathrm{p}=0.000,<0.05)$. The correlation analysis to determine the relationship between reverse logistics management and performance of performance of oil companies in Kenya, Pearson Correlation Coefficient computed and tested at 5\% significance level. The results indicate that there is a positive relationship $(\mathrm{r}=0.323)$ between information technology policy and performance of oil companies. In addition, the researcher found the relationship to be statistically significant at $5 \%$ level $(\mathrm{p}=0.000,<0.05)$. The correlation analysis to determine the relationship between early vendor involvement and performance of oil companies, Pearson Correlation Coefficient computed and tested at 5\% significance level. The results indicate that there is a positive relationship $(\mathrm{r}=0.628)$ value for early vendor involvement and performance of oil sector companies. In addition, the researcher found the relationship to be statistically significant 
at $5 \%$ level $(\mathrm{p}=0.000,<0.05)$. The correlation analysis to determine the relationship between green procurement and performance of oil sector, Pearson Correlation Coefficient computed and tested at 5\% significance level.

The results indicate that there is a positive relationship $(\mathrm{r}=0.676)$ between green procurement and performance of oil sector. In addition, the researcher found the relationship to be statistically significant at $5 \%$ level $(p=0.000,<0.05)$. Hence, it is evident that all the independent variables could explain the changes in the performance of companies in the oil sector on the basis of the correlation analysis.

Table 5 :Correlation results

\begin{tabular}{|c|c|c|c|c|c|c|}
\hline & & $\begin{array}{l}\text { Reverse Logistics } \\
\text { Management }\end{array}$ & $\begin{array}{c}\text { Information } \\
\text { Technology } \\
\text { Adoption } \\
\end{array}$ & $\begin{array}{c}\text { Early Vendor } \\
\text { Involvement } \\
\end{array}$ & $\begin{array}{c}\text { Green } \\
\text { Procurement } \\
\text { Adoption } \\
\end{array}$ & Performance \\
\hline \multicolumn{7}{|l|}{ Reverse } \\
\hline Logistics & Pearson & & & & & \\
\hline Management & Correlation & 1 & & & & \\
\hline $\begin{array}{l}\text { Information } \\
\text { Technology }\end{array}$ & Pearson & & & & & \\
\hline Adoption & $\begin{array}{l}\text { Correlation } \\
\text { Sig. (2-tailed) }\end{array}$ & $\begin{array}{c}289 * * \\
0\end{array}$ & & & & \\
\hline Early Vendor & Pearson & & & & & \\
\hline Involvement & $\begin{array}{l}\text { Correlation } \\
\text { Sig. (2-tailed) }\end{array}$ & $\begin{array}{c}.368^{* *} \\
0\end{array}$ & $\begin{array}{c}.344^{* *} \\
0\end{array}$ & 1 & & \\
\hline $\begin{array}{l}\text { Green } \\
\text { Procurement }\end{array}$ & Pearson & & & & & \\
\hline Adoption & $\begin{array}{l}\text { Correlation } \\
\text { Sig. (2-tailed) }\end{array}$ & $\begin{array}{c}.352 * * \\
0\end{array}$ & $\begin{array}{c}.457 * * \\
0\end{array}$ & $\begin{array}{c}.520^{* *} \\
0\end{array}$ & 1 & \\
\hline $\begin{array}{l}\text { Performance } \\
\text { of Companies }\end{array}$ & & & & & & \\
\hline $\begin{array}{l}\text { in the Oil } \\
\text { Industry }\end{array}$ & $\begin{array}{l}\text { Pearson } \\
\text { Correlation } \\
\text { Sig. (2-tailed) }\end{array}$ & $\begin{array}{l}.479 * * \\
0.000\end{array}$ & $\begin{array}{c}.323 * * \\
0.000\end{array}$ & $\begin{array}{l}.628 * * \\
0.000\end{array}$ & $\begin{array}{l}.676^{* *} \\
0.000\end{array}$ & 1 \\
\hline
\end{tabular}

\section{Regression Analysis}

The results of regression analysis revealed there is a significant positive relationship between dependent variable (performance and the independent variables (reverse logistics management, information technology adoption, early vendor involvement and green procurement adoption). The independent variables reported $\mathrm{R}$ value of .775 indicating that there is perfect relationship between dependent variable and independent variables. $\mathrm{R}$ square value of 0.6 means that $60 \%$ of the corresponding variation in performance of oil companies can be explained or predicted by reverse logistics management, information technology adoption, early vendor involvement and green procurement adoption, which indicated that the model fitted the study data. Adjusted R square in table 6 is called the coefficient of determination which indicates how performance of oil companies varied with variation in effects of factors which includes reverse logistics management, information technology adoption, early vendor involvement and green procurement adoption. The results of regression analysis revealed that there was a significant positive relationship between dependent variable and independent variable at $(\beta=0.309)$, $\mathrm{p}=0.002<0.05)$. 
International Journal of Supply Chain and

Logistics ISSN 2520-3983 (Online)

Vol. 3, Issue 2, pp 84 - 104, 2019

Table 6: Model Summary

\begin{tabular}{lllll}
\hline Model & R & R Square & Adjusted R Square & $\begin{array}{l}\text { Std. Error of the } \\
\text { Estimate }\end{array}$ \\
\hline 1 & $.775^{\mathrm{a}}$ & .60 & .586 & .16769 \\
\hline
\end{tabular}

The significance value is 0.000 which is less that 0.05 thus the model is statistically significance in predicting how reverse logistics management, information technology adoption, early vendor involvement, green procurement adoption influence performance among oil companies in Kenya.

The F critical at 5\% level of significance was 26.80. Since F calculated which can be noted from the ANOVA table above is 42.929 which is greater than the F critical (value $=26.80$ ), this shows that the overall model was significant. The study therefore establishes that; reverse logistics management, information technology adoption, early vendor involvement, green procurement adoption were all important factors influencing performance of oil companies. These results agree with Asaari and Razak (2010) results which indicated a positive and significant influence of supply chain sustainability on the performance of companies in the oil industry in Kenya.

Table 7: ANOVA

\begin{tabular}{|c|c|c|c|c|c|c|}
\hline Model & & $\begin{array}{l}\text { Sum } \\
\text { Squares }\end{array}$ & of $\mathrm{df}$ & Mean Square & $\mathbf{F}$ & Sig. \\
\hline \multirow[t]{3}{*}{1} & Regression & 4.809 & 4 & 1.202 & 42.929 & $.000^{\mathrm{b}}$ \\
\hline & Residual & 3.206 & 114 & 0.028 & & \\
\hline & Total & 8.014 & 118 & & & \\
\hline
\end{tabular}

The regression coefficients has established that taking all factors into account (reverse logistics management, information technology adoption, early vendor involvement and green procurement adoption) constant at zero, performance of oil companies will be an index of 2.44. The findings presented also shows that taking all other independent variables at zero, a unit increase in reverse logistics management will lead to a 0.146 increase in performance of oil companies. The P-value was 0.00 which is less than 0.05 and thus the relationship was significant. The study also found that a unit increase in information technology adoption will lead to a 0.03 increase in in performance of oil companies. The P-value was 0.03 and thus the relationship was significant. In addition, the study found that a unit increase in early vendor involvement will lead to a 0.11 increase in the performance of oil companies. The P-value was 0.00 and thus the relationship was significant. Lastly, the study found that a unit increase in green procurement adoption will lead to a 0.215 increase in the Performance of oil companies. The P-value was 0.00 and hence the relationship was significant since the $\mathrm{p}$-value was lower than 0.05. The findings of the study show that, green procurement adoption contributed most to the performance of oil companies in Kenya. 
International Journal of Supply Chain and

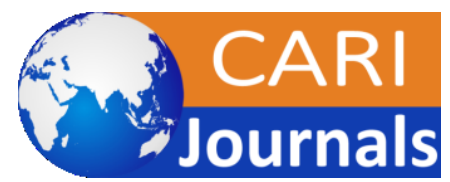

Logistics ISSN 2520-3983 (Online)

Vol. 3, Issue 2, pp 84 - 104, 2019

Table 8: Model of Coefficient

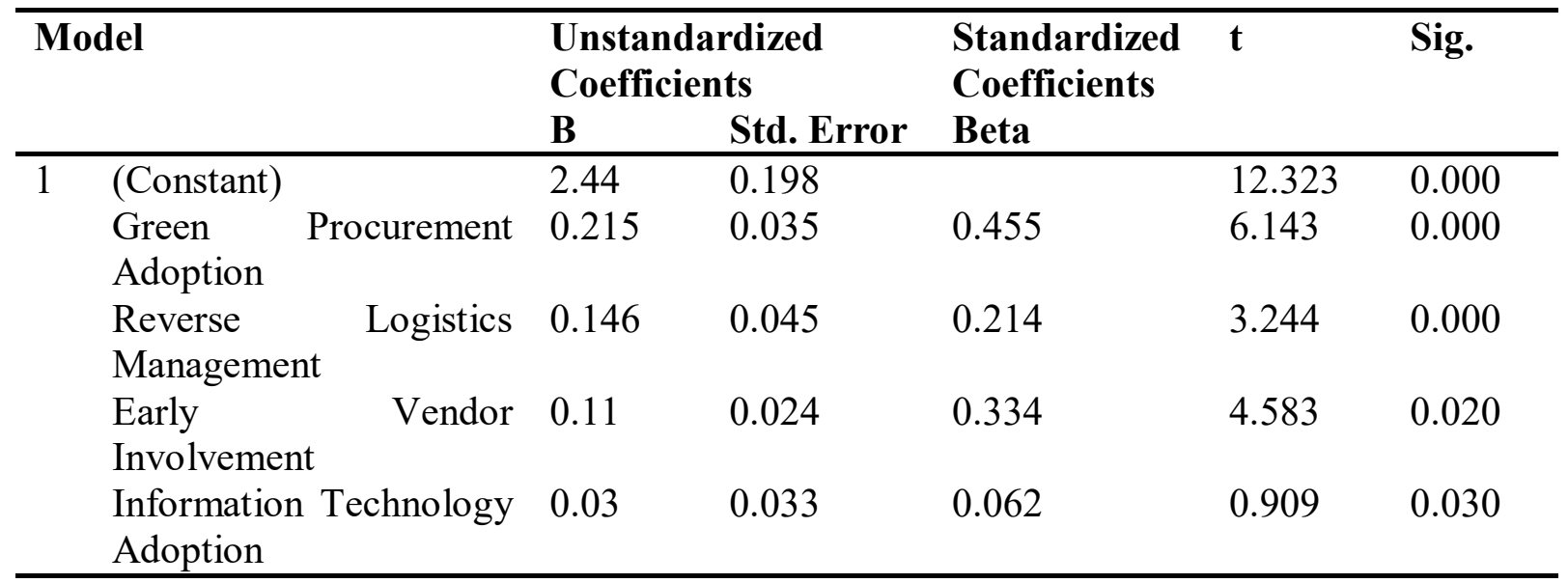

The regression equation becomes:

Performance of Companies in the Oil Industry $=2.44+0.146($ Reverse Logistics Management) $+\mathbf{0 . 0 3}$ (Information Technology Adoption) $+\mathbf{0 . 1 1 ( E a r l y ~ V e n d o r ~}$ Involvement) + 0.215(Green Procurement Adoption)

\subsection{CONCLUSIONS AND RECOMMENDATIONS}

\subsection{Conclusion}

First, in regard to green procurement adoption, the regression coefficients of the study show that it has a significant influence of 0.215 on performance of companies in the oil industry. This implies that increasing levels of green procurement adoption by a unit would increase the levels of performance of companies in the oil industry by 0.215 . This shows that green procurement adoption has a positive influence on performance of companies in the oil industry. Second in regard to reverse logistics management, the regression coefficients of the study show that it has a significant influence of 0.146 on performance of companies in the oil industry. This implies that increasing levels of reverse logistics management by a unit would increase the levels of performance of companies in the oil industry by 0.146 . This shows that reverse logistics management has a positive influence on performance of companies in the oil industry. With regard to early vendor involvement, the regression coefficients of the study show that it has a significant influence of 0.11 on performance of companies in the oil industry. This implies that increasing levels of early vendor involvement by a unit would increase the levels of performance of the companies in the oil industry by 0.11 . This shows that early vendor involvement has a positive influence on performance of companies in the oil industry. Lastly, in regard to the fourth objective, the regression coefficients of the study show that it has a significant influence of 0.03 on performance of companies in the oil industry. This implies that increasing levels of information technology adoption by a unit would increase the levels of performance of companies in the oil industry by 0.03 . This shows that information technology adoption has a positive influence on performance of companies in the oil industry. Drawing on this research, lack of reverse logistics management, information technology adoption, early vendor involvement and green procurement adoption in companies in the oil industry is leading to poor performance. Though the companies in the oil industry are striving hard to improve their 
International Journal of Supply Chain and

Logistics ISSN 2520-3983 (Online)

Vol. 3, Issue 2, pp 84 - 104, 2019

performance there are still issues of poor-quality products, long lead time and high cost of projects/products.

\subsection{Recommendations of the Study}

To ensure that companies in the oil industry have better performance they should focus more on using their reverse logistics practices so as to ensure that recycling and returns policies are clear and ensure that there is consistency of quality in goods supplied. In the same regard, they should involve suppliers early enough to enable them to come up with reverse logistics systems that drives the company towards remanufacturing and refurbishment. With regard to the second objective, it would be constructive for companies in the oil industry to invest more in information technology adoption to reduce the cost of procurement through unnecessary reworks and ensure professional suppliers get it right the first time. This should be done consistently with the partnerships, training and capacity building. This will include issues such as electronic data interchange. In relation to early vendor involvement, the organizations should align there goals with their vendors so as to have a more improved working relationship characterized by joint planning and systems integration. If companies in the oil industry embrace early vendor involvement among its suppliers then there will be cost reduction and timing of delivery will improve. Concerning green procurement adoption, there is need for companies in the oil industry to always set aside a substantial part of their resources for activities that spend a huge amount of total resources, and this entails eco-sourcing and eco-product designs. This is because decisions made here have major effects on sustainability measures. The study recommends that procurement staff in companies in the oil industry should ensure that they strictly follow procurement procedures to ensure that goods supplied are of the right quality, in the right quantity, at the right time, to the right place from the right source. This will aim at satisfaction of customers in terms of cost, quality, and timeliness of the delivered product or service, minimizing administrative operating costs, conducting business with integrity, fairness and openness.

\subsection{ACKNOWLEDGEMENT}

Sincere appreciation is to God who granted me the gift of life, a chance to education and the privilege of carrying out this project. I also thank Dr. Allan Kihara my supervisor as well as the head of EPD department for the continuous assistance, in the entire process of writing this project. Finally my heartfelt thanks go to my family for their prayers and encouragement.

\section{REFERENCES}

Amol, S., \& Ashish, T. (2016). "Sustainable green supply chain management: trends and current practices", Competitiveness Review, 26(3), 265-288.

Anne, T., \& Hellen, W. (2015). "Theories in sustainable supply chain management: a structured literature review", International Journal of Physical Distribution and Logistics Management, 45(2), 16-42.

Baumann-Pauly, D. (2013). Managing corporate legitimacy: A toolkit. Sheffield, UK: Greenleaf Publishing.

Beske, P., \& Seuring, S. (2014). "Putting sustainability into supply chain management". Supply Chain Management: An International Journal, 1(9), 322-331. 
International Journal of Supply Chain and

Logistics ISSN 2520-3983 (Online)

Vol. 3, Issue 2, pp 84 - 104, 2019

Brettel, M., \& Voss, U. (2013). "Antecedents of management control combinations-An explanation from resource dependence theory". Schmalenbach Business Review, 6(5), 409-430.

Buysse, K., \& Verbeke, A. (2013). Proactive environmental strategies: a stakeholder management perspective. Strategic Management Journal, 24(5), 453-470.

CCG (2014). National Development Fund Report Instructional Structures and Reforms. Nairobi: Centre for Corporate Governance.

Chien, M. K., \& Shih, H. (2011). An empirical study of the implementation of green supply chain management practices in the electrical and electronic industry and their relation to organizational performances. International Journal of Environmental Science and Technology, 4(3), 383-401.

Christmann, P. (2010). Effects of "best practices" of environmental management on cost advantage: The role of complementary assets. Academy of Management journal, 43(4), 663-680.

Christopher, M. (2010). The agile supply chain: competing in volatile markets. Industrial marketing management, 29(1), 37-44.

CIPS (2012). Sustainable Procurement Practices. Retrieved from: https://www.cips.org. November 2017.

Croom, S., \& Jones, A. (2010). E-procurement: Key Issues in inventory control implementation and operation in the public sector.

Davila, A. (2010). The adoption and the use of inventory control technology model, European Management Journal, 21(1), 11-23.

Donaldson, T., \& Preston, L. (2015). 'The Stakeholder Theory of the Corporation: Concepts, Evidence, and Implications.' Academy of Management Review, 20(1), 65-91.

Drees, J. M., \& Heugens, P. P. (2013). "Synthesizing and extending resource dependence theory: A meta-analysis". Journal of Management, 3(9), 1666-1698.

Duber, D. C. (2012). The Green Imperative. Soap, Perfumery, and Cosmetics, 78 (8), 24-26.

Fouka, G., \& Mantzorou, M. (2011). "What are the major ethical issues in conducting research? Is there a conflict between the research ethics and the nature of nursing?" Health Science Journal, 5(1), 3-14.

Freeman, R. E., \& Phillips, R. A. (2012). Stakeholder theory: A libertarian defense. Business Ethics Quarterly, 24(5), 331-349.

Frooman, J. (2015). ‘Stakeholder Influence Strategies.' Academy of Management Review, 24(2), 191-205.

Grandia, J., Steijn, B., \& Kuipers, B., (2015). It is not easy being green: Increasing sustainable public behavior, Innovation. The European Journal of Social Science Research.

Greeno, J., \& Robinson, S. (2012). Rethinking corporate environmental management. The Columbia Journal of World Business, 3(1), 222-232. 
International Journal of Supply Chain and

Logistics ISSN 2520-3983 (Online)

Vol. 3, Issue 2, pp 84 - 104, 2019

Hall, J., \& Matos, S. (2010). Incorporating impoverished communities in sustainable supply chains International Journal of Physical Distribution \& Logistics Management, 40(1), 124-147.

Harrison, J., \& Freeman, J. (2015). New CEOs pursue their own self-interests by sacrificing stakeholder values. Journal of Business Ethics, 1(9), 301-308.

Helen, W., \& Stephen, B. (2010). Sustainable Procurement in South African Public Sector. University of Bath, School of Management Working Paper Series.

Henriques, I., \& Sadorsky, P. (2015). The relationship between environmental commitment and managerial perceptions of stakeholder importance. Academy of Management Journal, 42(1), 87-99.

Hoffman, A. J. (2011). Institutional evolution and change: Environmentalism and the US chemical industry. Academy of management journal, 42(4), 351-371.

Islam, M. A. (2014). Social compliance accounting: Managing legitimacy in global supply chains.

Jha, R. (2010). Customer focused collaborative demand planning in Hi-Tech Industry, Massachusetts Institute of Technology, USA.

Kitheka, S. (2012). Inventory management automation and the performance of supermarkets in western Kenya, Unpublished MBA Project, University of Nairobi, Nairobi.

Lehtonen, M. (2014). "The environmental social interface of sustainable development: capabilities, social capital, institutions "Ecological Economics, 49(2), 199-214.

Mugenda, O., \& Mugenda, A. (2014). Research methods quantitative and qualitative approaches. Nairobi: Acts Press.

Noor, R. (2011). Supply chain management practices in Malaysia oil and gas industry: A case of Murphy Sarawak Oil Company Ltd.

Orodho, A. J. (2014). Research Methods. Nairobi: Kenyatta University Institute of Open Learning.

Reinhardt, F. (2015). Market failure and the environmental policies of firms: Economic rationales for "beyond compliance" behavior. Journal of Industrial Ecology, 3(1), 9-21.

Samuelson, O. (2013). The IT-Barometer-A Decade's Development of its Use in The Swedish Construction Sector. Journal of Information Technology in Construction, 13 (5), 1-19.

Sarkis, J. (2012). "A boundaries and flows perspective of green supply chain management", Supply Chain Management, 1(7), 202-216.

Shirima, D. L. (2013). Value for Money Through Reduced Procurement Transaction Costs and Improved Efficiency. Tanzania Procurement Journal , 1(1), 44-52.

Spence, L., \& Bourlakis, M. (2015). "The evolution from corporate social responsibility to supply chain responsibility: the case of Waitrose", Supply Chain Management: An International Journal, 14(4), 291-302. 
International Journal of Supply Chain and

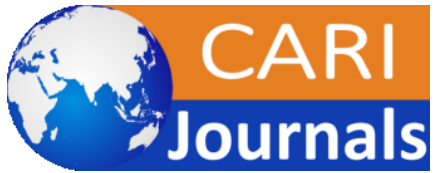

Logistics ISSN 2520-3983 (Online)

Vol. 3, Issue 2, pp 84 - 104, 2019

Stephen, B., \& Helen, W., (2012). Sustainable Procurement Practice in the Public Sector: An International Comparative Study, University of Bath, School of Management. Working Paper Series.

Swalehe, S., \& Odock, S. (2015). Effect of Eco-design practices on the performance of manufacturing firms in Mombasa county Kenya, University of Nairobi. Unpublished.

USAID (2014). Selecting and implementing green supply chains systems for oil sector supply chain: Deliver Project, USAID.

World Bank (2014). World Bank Procurement Reform: New Direction Endorsed. Press Release No: 2014/057/OPCS. 